\title{
The effect of emulsification of a milk-substitute diet by mechanical homogenization and by the addition of soya- bean lecithin on plasma lipid and vitamin $A$ levels and on the growth rate of the newborn calf
}

\author{
By J. H. B. ROY, K. W. G. SHILLAM, S. Y. THOMPSON \\ AND DIANA A. DAWSON \\ National Institute for Research in Dairying, Shinfield, Reading
}

\section{(Received 20 February 1961-Revised 9 fune 196I)}

Although experiments on the effect of inclusion of vegetable or animal fats in synthetic milks (Wiese, Johnson, Mitchell \& Nevens, I947; Lofgreen, I950; Kastelic, Bentley \& Phillips, 1950) or in milk substitutes based on dried skim-milk powder (Gullickson, Fountaine \& Fitch, I942) have been made over a number of years, it is only comparatively recently that milk substitutes consisting basically of skim milk and added fat have been used commercially. This development has come from an increasing interest in veal production which, especially on the continent of Europe, takes the form of intensive production that requires a specialized diet of high energy content, which at the moment can most economically be achieved by utilizing fats other than butterfat. However, the type of added fat and also the method by which it is incorporated into the skim milk is of great importance owing to the sensitivity of the calf to dietary changes, particularly during the ist month of life.

Gullickson et al. (I942) obtained very poor results with homogenized-milk diets containing $3.5 \%$ of either cottonseed, soya-bean or maize oil, but the animal fats, lard and tallow, gave moderately good results and coconut oil gave an intermediate response. These workers reported loss of hair, first from the face, ears and neck and later from the cannons of the rear legs, of calves given the maize, cottonseed or soyabean oil. Bate, Espe \& Cannon (1946), however, associated similar hair losses with unhomogenized diets, whereas de Man (I95I) found that diets containing unhydrogenated soya-bean oil caused hair loss and development of eczema due to excretion of oil through the skin, whereas hydrogenated soya-bean oil had much less effect. Even when homogenized, unhydrogenated soya-bean oil has been found to cause a poor rate of growth, rough hair coats and a high incidence of scouring and mortality (Jacobson \& Cannon, I947; Wiese et al. 1947; Jacobson, Cannon \& Thomas, 1949; Murley, Jacobson, Wise \& Allen, I949; Barker, Wise \& Jacobson, I952; Adams, Gullickson, Gander \& Sautter, I959), but diets containing hydrogenated soya-bean oil have given results nearly as good as those containing butter oil (Murley et al. 1949).

Raven \& Robinson (1958, I959, I960) have studied the nutritive value of palm oil and palm-kernel oil for the calf, and have found the digestibility of both hydrogenated 
and unhydrogenated forms to be lower than that of butterfat. The hydrogenated palm oil appeared to have a lower protein-sparing effect than the unhydrogenated oil; however, these oils were not compared directly in the same experiment.

The finding of Gullickson et al. (1942) that lard and tallow appeared to be well utilized by the calf has been confirmed by many workers (Wiese et al. I 947 ; Blaxter \& Wood, 195I; Johnson, Hopper \& Gardner, 1953; Hopper, Gardner \& Johnson, 1954; Ritchey, Hopper, Gardner \& Johnson, 1956; Thomas \& Okamoto, 1956; Bell, 1958; Larsen, 1958; Comberg \& Göllnitz, 1959; Kliesch \& Horst, I959; Kesler, Wilson \& Moore, 1960), but Jacobson, Brown \& Ratcliff (1959) found that the incidence of scouring was higher with a diet containing lard than with whole milk.

Lard and tallow appear to be of equal value, but Brüggemann \& Barth (1959) found that the digestibility of lard was superior to that of beef suet, although both were well digested from $\mathrm{r} 5$ to 60 days of age. Hydrogenated herring oil has been used in Norway (Homb, 1960), but the calves did not grow as well as those given butterfat, though both groups were much superior to those given coconut fat, which caused severe scouring.

Nearly all the diets containing added fats so far mentioned have been mechanically homogenized since there is general agreement that for efficient utilization some form of treatment is necessary to reduce the size of the fat globules. Kastelic et al. (1950) found that, when a synthetic milk containing I $\%$ cottonseed oil was emulsified with soya-bean lecithin in a Waring Blendor, a calf given the diet scoured within 2 days. However, when a mixture of water, cottonseed oil and lecithin that had been homogenized at a pressure of $\mathrm{I} 800 \mathrm{lb} / \mathrm{in}^{2}$ until the oil globules were $2 \mu$ or less in diameter was given to this calf (now 12 days of age), the diarrhoea stopped within $36 \mathrm{~h}$. On the basis of this slender evidence it has been assumed that a fat globule size of less than $2 \mu$ should be aimed at in milk substitutes for calves.

There is little doubt that the size of fat globule is of importance, for the smaller the globule the greater is the rate of digestion, and with a large proportion of small globules more protein may be adsorbed on the globule surfaces. The diameter of fat globule in cow's milk varies from 0.1 to IO $\mu$ with an average of $3-4 \mu$ (dalla Torre, 1953; Ling, Kon \& Porter, 1961), and cow's milk that contains large fat globules also tends to form a tougher curd than one containing small globules (Clements, 1949). Recently, it has been suggested that rats given homogenized milk ad lib. gain more in live weight and utilize protein better than those fed on an untreated milk (Petrilli \& Agnese, 1960). Moreover, it has been suggested that the small fat globules of butter and high-quality margarine can be absorbed intact, but other fats (olive oil and some margarines) have to be emulsified first and are passed through the intestinal wall mainly as fat degradation products and only partly as fine emulsions (Haubold, Heuer \& Rohusinskyi, I960).

The use of emulsifying agents as an alternative to homogenization has been studied for some years. Huff, Waugh \& Wise (195I) observed a loss of hair in calves when glycerol monostearate was used as the emulsifying agent in a diet containing hydrogenated cottonseed oil, but when the diet was homogenized the characteristic alopecia 
was absent; recently Hopkins, Warner \& Loosli (1959) have shown that emulsification of coconut fat with crude soya-bean lecithin resulted in a very large increase in apparent digestibility of the fat, and mechanical homogenization of the diet had no additional beneficial effect. However, these calves were given antibiotics and the digestion trials were not made until the calves were 2-3 weeks of age. Increased digestibility of certain fats with increasing age of the calf has been observed by Cunningham \& Loosli (1954), Lassiter, Duncan \& Christie (1957) and Brüggemann \& Barth (1959).

Hodgson \& Murdock (1960) found that a milk substitute containing on a dry-matter basis $10 \%$ stabilized lard together with skim milk, whey and buttermilk caused significantly greater weight gains in calves when the lard was homogenized in the buttermilk than when the fat was just physically blended, but they do not mention whether an emulsifying agent was used. Both diets gave better results than a milk substitute containing no fat.

In many of our experiments we have used margarine in a milk substitute and have obtained apparent digestibilities of fat of up to $98 \%$ during the first 3 weeks of life (Shillam, 1960). However, the mixture had always been homogenized at a pressure of $200 \mathrm{~atm}$. It was therefore of interest to know whether lecithin could be used as a substitute for mechanical homogenization and whether its inclusion in a diet had any beneficial effect other than that resulting from its role as an emulsifying agent. In earlier work (Aschaffenburg, Bartlett, Kon, Roy, Sears, Thompson, Ingram, Lovell $\&$ Wood, 1953) it was shown that the inclusion of lecithin in the first two feeds of life greatly increased the absorption of vitamin A, but this effect may have been particularly marked during this time when the intestine was permeable to the passage of whey proteins into the lacteals (Comline, Roberts \& Titchen, I95 I). However, it is known that lecithin increases the rate of absorption of lipids in rats and in man (Adlersberg \& Sobotka, 1943; Augur, Rollman \& Deuel, I947; Tidwell, 1950).

The effect of soya-bean lecithin was therefore studied in three experiments. In the first, two forms of soya-bean lecithin, a crude and a pharmaceutical grade, were compared. They were included in a milk-substitute diet into which the margarine had been mechanically homogenized. In the second and third experiments, mechanical homogenization of margarine fat was compared with emulsification with lecithin.

\section{METHODS}

\section{Plan of experiments}

All three experiments were of randomized block design.

Expt I. It was done in the early months of 1959 and consisted of three treatments in each of six blocks, four of Ayrshire bull calves and two of Shorthorn, as follows:

Treatment no.

$\left.\begin{array}{l}1 \\ 2 \\ 3\end{array}\right\}$
Basal diet

Reconstituted spray-dried skim milk containing $2 \%$ margarine incorporated by homogenization
Lecithin given

None

Pharmaceutical grade

Crude grade 
Expt 2. It was done in the autumn and winter of 1959 and consisted of four treatments in each of twelve blocks, eight of Ayrshire bull calves and four of Shorthorn, as follows:

$\left.\begin{array}{c|c}\text { Treatment no. } & \text { Basal diet } \\ 4 \\ 6\end{array}\right\} \begin{aligned} & \text { Method of incorporating fat } \\ & \begin{array}{l}\text { Reconstituted spray-dried skim milk } \\ \text { containing } 2 \% \text { margatine }\end{array}\end{aligned} \quad \begin{aligned} & \begin{array}{l}\text { Homogenization } \\ \text { Homogenization and emulsification } \\ \text { with the pharmaceutical grade of } \\ \text { lecithin } \\ \text { Emulsification with the pharma- } \\ \text { ceutical grade of lecithin } \\ \text { No emulsification or homogenization }\end{array} \\ & \text { N }\end{aligned}$

Expt 3. This was done in the early summer of 1960 and consisted of two treatments in each of twelve blocks, ten of Ayrshire bull calves and two of Shorthorn, as follows:

$\left.\begin{array}{c}\text { Treatment no. } \\ 8 \\ 9\end{array}\right\}$
Basal diet

Reconstituted spray-dried skim milk, containing $2 \%$ margarine
Method of incorporating fat

Homogenization

Emulsification with the pharmaceutical grade of lecithin before reconstitution

\section{Diets}

Colostrum. Colostrum obtained within 24 h of calving from Shorthorn and Ayrshire cows was used; I-pint samples were stored separately in waxed-paper cartons at $-25^{\circ}$. Each calf was given initially 6 pints of colostrum consisting of I pint from each of six different batches. Calves within each block received the same blend of colostrum, but there were differences in the blend between the blocks.

Milk-substitute diets. The basal diet consisted of margarine fat and of reconstituted spray-dried skim-milk powder that had been processed at a pre-heating temperature of $77^{\circ}$ for ${ }_{5} 5 \mathrm{sec}$ only and in which no apparent denaturation of the non-casein protein had occurred (Shillam, I960; Shillam, Dawson \& Roy, I960).

The margarine contained no additional vitamins and consisted of approximately $39 \%$ groundnut oil, $24 \%$ palm oil and $37 \%$ coconut oil, of which a proportion was in the form of hardened oil. The lecithin content of the margarine was about $0.003 \%$ but approximately $0.18 \%$ of emulsifiers ('monoglyceride based on fully hardened groundnut oil') was included during manufacture.

For the diets used in treatment $\mathrm{I}$ of Expt $\mathrm{I}$, treatment 4 of Expt 2 and treatment 8 of Expt 3, a milk of $20 \%$ fat content was prepared by homogenizing $2 \mathrm{lb}$ non-vitaminized margarine into a reconstituted mixture of $0.8 \mathrm{lb}$ spray-dried skim-milk powder in $7 \cdot 2 \mathrm{lb}$ water. It was made once or twice weekly, a maximum of $50 \mathrm{lb}$ being prepared at any one time, and stored at $4^{\circ}$ until required. A small single-action type of homogenizer was used, working at a pressure of $200 \mathrm{~atm}$; a stirrer was fitted close to the inlet so that the fluid entered the machine in a well-mixed condition.

Each Io lb batch of the basal diet was prepared by reconstituting $0.9 \mathrm{lb}$ of skim-milk powder with $8 . \mathrm{I} \mathrm{lb}$ of water to which was added $\mathrm{I}$ lb of the milk of $20 \%$ fat content.

Lecithin. In Expt $\mathbf{r}$ two forms of soya-bean lecithin (American Lecithin Company Inc.) were used: one, Alcolec S, a feeding grade in a carrier of soya-bean oil with a 
phosphatide content of $62-65 \%$, and the other, Alcolec granules, a pharmaceutical grade made by repeated washing of the Alcolec $\mathrm{S}$ with acetone to remove the soyabean oil and containing $95 \%$ of phosphatides (J. Eichberg, I959, personal communication). Before homogenization $47.8 \mathrm{~g}$ of Alcolec granules were dissolved in each $2 \mathrm{lb}$ of margarine used in the preparation of the diet given to calves on treatment 2 and $69.8 \mathrm{~g}$ of Alcolec $\mathrm{S}$ in each $2 \mathrm{lb}$ of margarine used in the diets given to calves on treatment 3 . Thus the final concentration of lecithin was $0.1 \%$.

In Expt 2, only the pharmaceutical grade of lecithin was used at a concentration of $0.2 \%$. For treatment $5,95.6 \mathrm{~g}$ of Alcolec granules were added to each $2 \mathrm{lb}$ margarine before homogenization. For treatment 7 , each Io lb batch of milk of $20 \%$ fat content was prepared by stirring $2 \mathrm{lb}$ of the melted fat into $0.8 \mathrm{lb}$ skim-milk powder dissolved in $7.2 \mathrm{lb}$ of water; for treatment $6,95.6 \mathrm{~g}$ of Alcolec granules were first added to the melted fat.

In Expt 3, melted fat containing the pharmaceutical grade of lecithin at a concentration of $2 \%$ was poured slowly into the skim-milk powder as it was stirred in a Hobart mixer. Stirring was continued for $5^{-10}$ min until the mixture became cream-like in consistency; it was then cooled to $4^{\circ}$. This mixture was diluted with water to give a diet containing $2 \%$ margarine and $0.2 \%$ lecithin.

Each calf received 3500 i.u. vitamin $A$ in the form of halibut-liver oil concentrate and 700 i.u. synthetic vitamin $\mathrm{D}_{3}$ daily, both vitamins being dissolved in arachis oil. The diets were given in quantities that had been found adequate for a growth rate of I lb/day when whole milk of $3.3 \%$ fat content was used (Roy, Shillam, Hawkins \& Lang, 1958).

\section{Calves}

The calves were reared for 3 weeks; collection and management were as in earlier experiments (Aschaffenburg, Bartlett, Kon, Terry, Thompson, Walker, Briggs, Cotchin \& Lovell, 1949). If a calf scoured, the quantity of milk was reduced to that calculated to maintain body-weight (Roy et al. 1958). When the consistency of the faeces returned to normal, the volume of milk was increased to the normal daily allowance. This practice was repeated when scouring recurred.

The mean dry-matter content of the faeces was calculated for each calf during the experimental period from daily subjective grading of the consistency of the faeces on a scale increasing from $\circ$ (severe diarrhoea) to 7 (very firm faeces). The mean values obtained from dry-matter determinations on several hundred samples of faeces were:

$\begin{array}{lllrrrrrr}\text { Grade } & 0 & 1 & 2 & 3 & 4 & 5 & 6 & 7 \\ \text { Dry matter (\%) } & 5 & 7 & 10 & 14 & 22 & 26 & 28 & 32\end{array}$

Jugular blood was drawn from all the calves in Expts $\mathrm{I}$ and 2 before their first feed and about $4 \mathrm{~h}$ after their morning feed on the 4 th, 12th and 2ist days of age. Total plasma lipids were extracted by the method of Jacobson, Zaletel \& Allen (1953). After weighing the fat, vitamin A was chromatographically separated (Ganguly, Kon \& Thompson, 1947). 


\section{RESULTS}

Expt $\mathrm{I}$. The results are given in Tables $\mathrm{I}$ and 2. The addition of the pharmaceutical grade of lecithin to the homogenized diet had no effect on the performance of the calves. However, calves given lecithin in a soya-bean oil carrier showed a significantly greater incidence of a high rectal temperature $\left(>102.8^{\circ} \mathrm{F}\right)$ and, after adjustment for differences between treatment groups in mean milk consumption and incidence of scouring, a significant increase in live-weight gain/day. The relevant partial regression coefficients with their standard errors were:

$$
\begin{aligned}
& \begin{array}{cc}
\text { General } & \begin{array}{c}
\text { Partial regression } \\
\text { coefficient with its } \\
\text { mean }
\end{array} \\
\text { standard error }
\end{array} \\
& \text { Live-weight gain/day (lb) } \\
& \text { Total milk consumption (pints) } \\
& \text { No. of days on which scouring occurred } \\
& \text { (values transformed } \sqrt{ }\left(x+\frac{1}{2}\right) \text { ) } \\
& 0.690 \\
& 158.7 \mathrm{I} \\
& \text { I. I } 58-0.1924 \pm 0.0519^{* *}
\end{aligned}
$$

As shown in Table 2, the addition of lecithin had no apparent effect on plasma lipids during the first I2 days of life; the levels rose more or less uniformly throughout the experimental period except for calves given the crude grade, which showed a fall between the 12 th and 2 rst days. With all treatments the plasma content of vitamin $A$ rose rapidly during the first 4 days of life, but this rise was followed by a slight fall to the I 2th day. The plasma vitamin A levels of the calves given the diet containing the crude lecithin continued to fall to the 2 ist day whereas those of the calves on the other two diets showed a slight rise; the difference was significant.

Expt 2. The results are given in Tables 3 and 4 . Diets prepared without homogenization resulted in very poor live-weight gains; inclusion of lecithin in the homogenized diet had no significant effect on live-weight gain, but there was some suggestion of an effect with the unhomogenized diet. After adjustment of live-weight gain for differences between treatment groups in mean birth weight and milk consumption the effect of lecithin was still not significant. The relevant partial regression coefficients were:

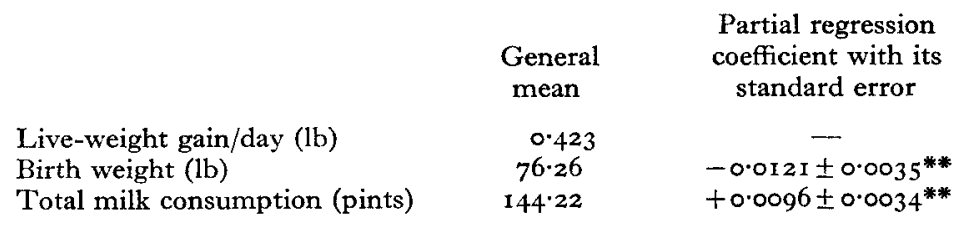

** Significant at $0.001<P<0.01$.

No difference between treatments in the incidence of scouring was apparent, but the estimated mean dry-matter content of the faeces was increased both by homogenization and by emulsification with lecithin.

Loss of hair on the head and legs was apparent to a marked extent only in calves given the unhomogenized and unemulsified fat; unaltered fat was plainly visible in the faeces of these calves, especially during the ist fortnight of life. 
Table 1. Expt 1. Comparison of the performance (mean values with their standard errors) of calves given homogenized milk-substitute diets containing two different preparations of soya-bean lecithin

$\overbrace{\text { I }}^{\text {Treatment no. and details }} \underbrace{\begin{array}{c}\text { Significance of } \\ \text { difference } \\ \text { between } \\ \text { treatments }\end{array}}_{\begin{array}{c}\text { Granular lecithin } \\ \text { No lecithin } \quad \begin{array}{c}\text { Lecithin in soya- } \\ \text { bean oil carrier }\end{array}\end{array}}$

No. of calves

Birth weight (lb)

Total milk consumption (pints)

Live-weight gain/day (lb)

No. of days on which calves scoured

Dry matter in faeces (\%)

No. of days on which calves had a

high rectal temperature $\left(>\mathrm{IO} 2.8^{\circ} \mathrm{F}\right.$ )

Adjusted live-weight gain/day (lb) $\dagger$

6
$84.0 \pm 3.51$
$164.5 \pm 4.42$
$0.77 \pm 0.073$
$0($ range $0-1)$
$23.0 \pm 1 \cdot 0$
$0($ range $0-2)$
$0.67 \pm 0.041$

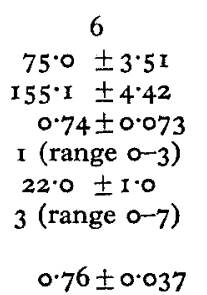

* Significant at $0.01<P<0.05$.

$\dagger$ Adjusted for differences between treatment groups in mean milk consumption and incidence of scouring.

I Overall mean value for treatments $I$ and 2 .

Table 2. Expt $\mathrm{x}$. Comparison of levels of blood plasma lipids and vitamin $A$ (mean values with their standard errors) of calves given homogenized milk-substitute diets containing two different preparations of soya-bean lecithin

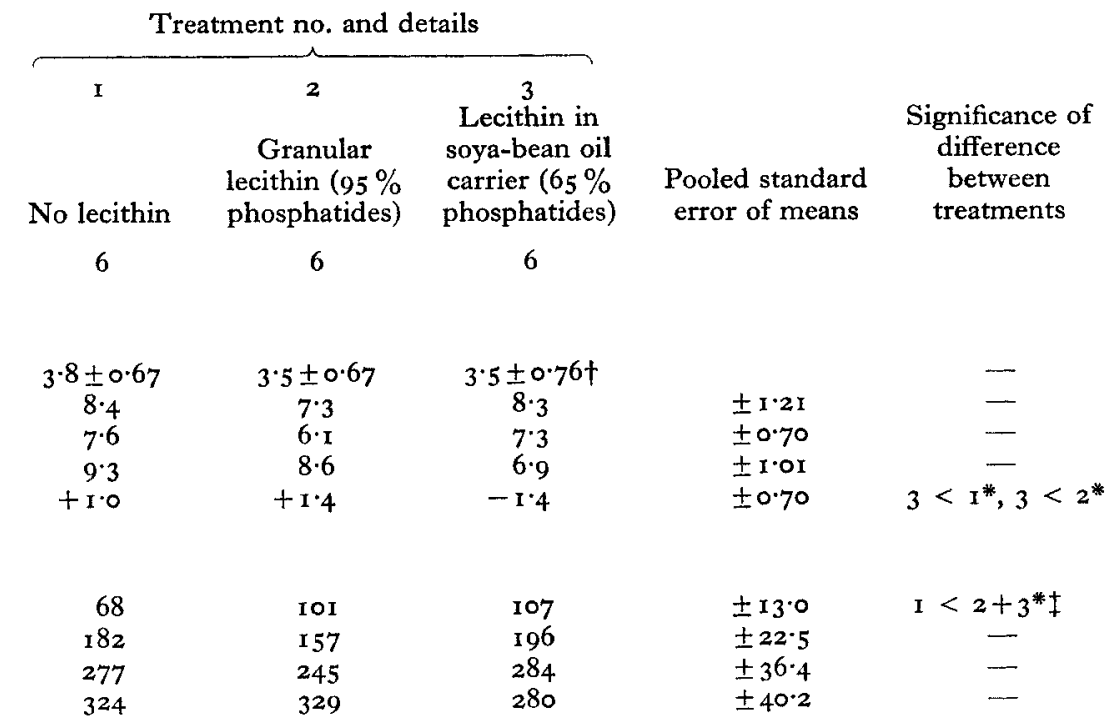

No. of calves

Blood plasma vitamin A

$(\mu \mathrm{g} / \mathrm{I}$ oo $\mathrm{ml})$ :

At birth

At 4 days

At 12 days

At 21 days

Increase, $4^{\text {th-2 }}$ ist day

Blood plasma lipids

(mg/roo ml):

$\begin{array}{lrr}\text { At birth } & 68 & \text { 10I } \\ \text { At } 4 \text { days } & 182 & 157 \\ \text { At I2 days } & 277 & 245 \\ \text { At } 2 \text { I days } & 324 & 329\end{array}$

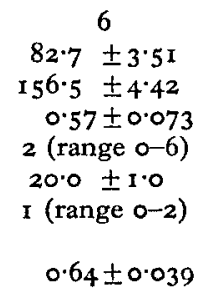

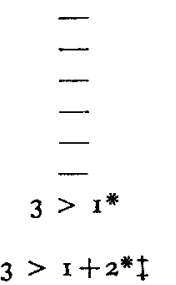

* Significant at $0.01<P<0.05$.

+ One sample not analysed. Missing value calculated by the missing-plot technique of Yates (1933).

\pm Overall mean value for treatments 2 and 3 . 


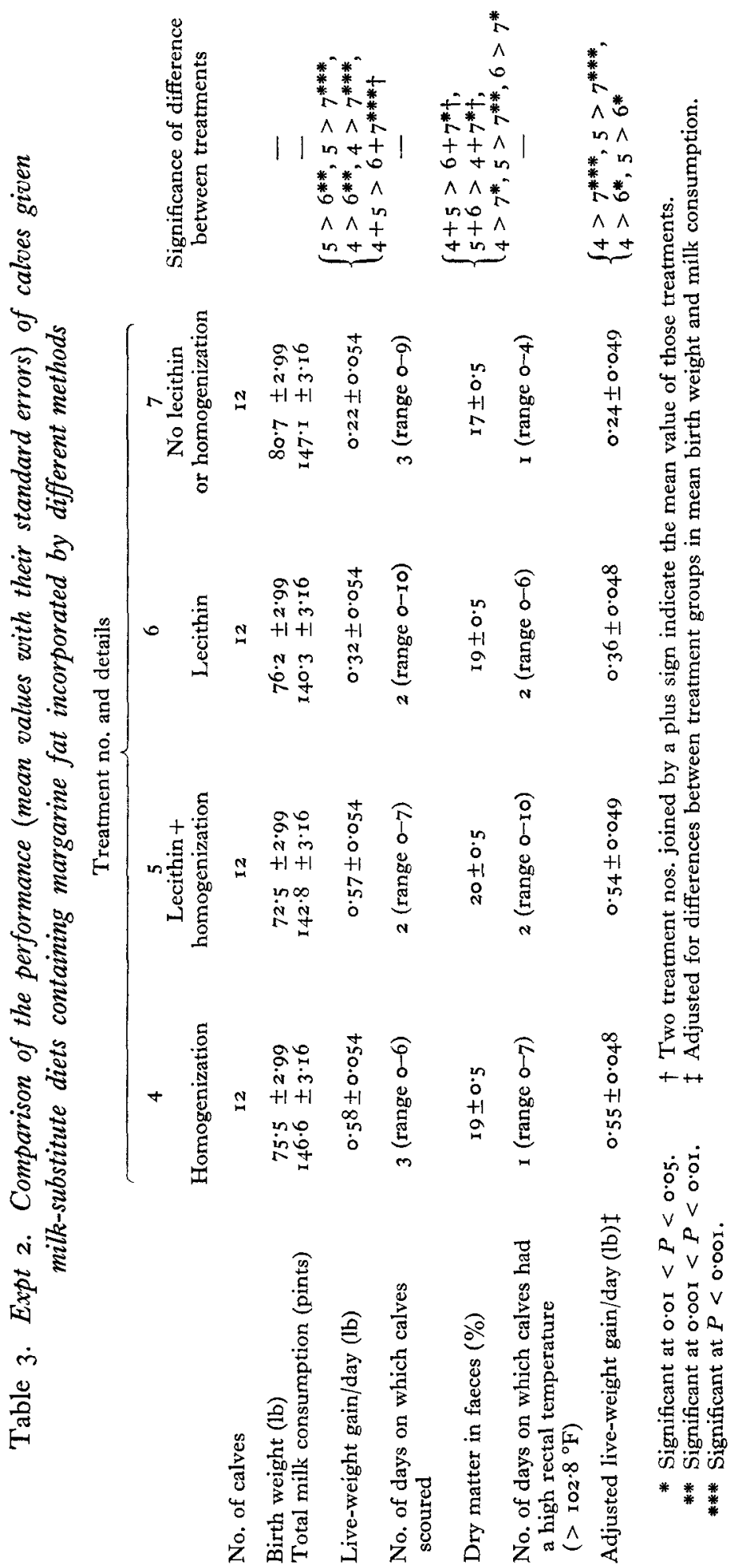




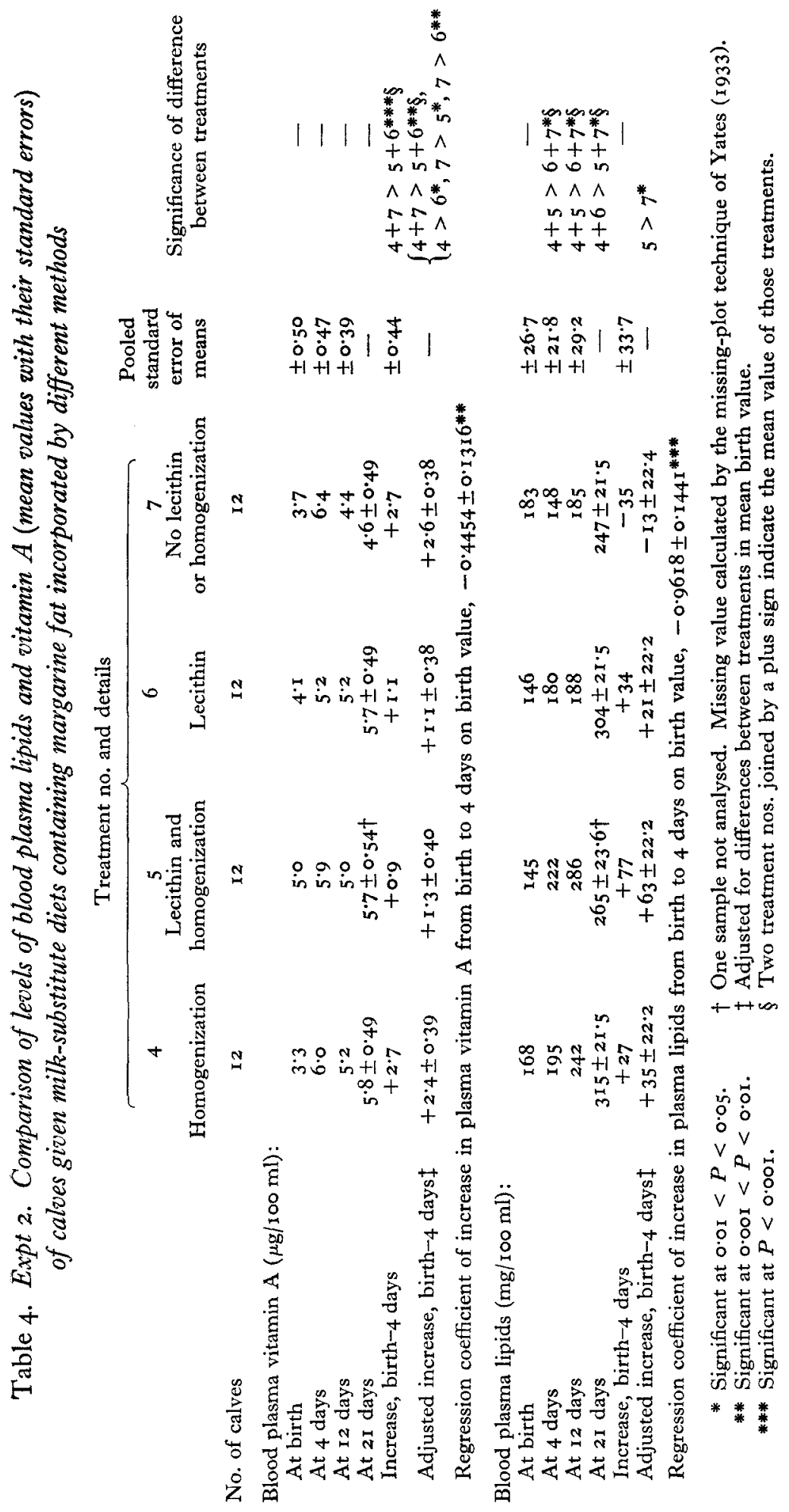


Microscopic examination of the size of fat globule in the diets showed that the mean diameter of the homogenized globule was about $3^{-4 \mu}$, and that the globules in the product emulsified with lecithin were probably of the mean size of $10-20 \mu$ with some as large as $5 \circ \mu$.

As is apparent from Table 4 , lecithin at this level of $0.2 \%$ significantly depressed the increase in plasma vitamin A levels between birth and the $4^{\text {th }}$ day of life. After adjustment of the increase for differences in the value of vitamin $A$ at birth by means of the regression coefficient given in Table 4 , the effect was still significant. The interaction of lecithin and homogenization was significant when the increase in vitamin $A$ levels from the $4^{\text {th }}$ to the $\mathrm{I}$ th day of life was analysed. However, the decline in plasma vitamin $A$ between the $4^{\text {th }}$ and I2th days was significantly greater for calves given the unemulsified fat than for those on the other three treatments.

Plasma lipid values on the $4^{\text {th }}$ and 12 th days of life were significantly increased by homogenization, whereas lecithin was ineffective. The increase in content of plasma lipids from birth to 4 days of age, after adjustment for the value at birth, was much greater for calves given the diet that was both emulsified and homogenized than for calves given unemulsified fat. However, the plasma lipid value for the 2 rst day indicated that homogenization and emulsification with lecithin were having an antagonistic effect. Thus the increase in levels of plasma lipids of calves given the diet that was both homogenized and emulsified was similar to that obtained for those given a diet containing unemulsified fat.

Table 5. Expt 3. Comparison of the performance (mean values with their standard errors) of calves given milk-substitute diets containing margarine fat incorporated either by homogenization into reconstituted skim-milk powder or together with lecithin directly into the dry powder

No. of calves

Birth weight (lb)

Total milk consumption (pints)

Live-weight gain/day (lb)

No. of days on which calves scoured

No. of days on which calves had a

high rectal temperature $\left(>102 \cdot 8{ }^{\circ} \mathrm{F}\right)$
Adjusted live-weight gain/day (lb) $\ddagger$

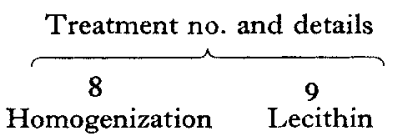

8

$8 \mathrm{r} \cdot 3 \stackrel{12}{ \pm 2} \cdot 74$

$149 \cdot 7 \pm 1 \cdot 91$

$0.49 \pm 0.055$

3 (range $\mathrm{I}-7$ )

I (range $0-5$ ) $0.48 \pm 0.033$

$$
\begin{gathered}
\text { I I } \\
83.7 \pm 2.98 \dagger \\
152.2 \pm 2.08 \dagger \\
0.35 \pm 0.060 \dagger \\
3 \text { (range } 0-5) \\
2 \text { (range } 0-6 \text { ) } \\
0.36 \pm 0.036 \dagger
\end{gathered}
$$

Significance of difference between treatments.

* Significant at $0.01<P<0.05$.

$\uparrow$ Missing value calculated by the missing-plot technique of Yates (1933).

$\ddagger$ Adjusted for differences between treatment groups in mean birth weight and milk consumption.

Expt 3. The results are given in Table 5. One calf given the diet in which the fat was emulsified with lecithin died from an Escherichia coli localized intestinal infection. As in Expt 2, the mean growth rate of the calves given the homogenized diet, after adjustment for differences between treatment groups in mean birth weight and milk consumption, was greater than that of calves given the diet in which the fat was. 
emulsified with lecithin. The partial regression coefficients used for the adjustment were:

\begin{tabular}{|c|c|c|}
\hline & $\begin{array}{c}\text { General } \\
\text { mean }\end{array}$ & $\begin{array}{l}\text { Partial regression } \\
\text { coefficient with its } \\
\text { standard error }\end{array}$ \\
\hline Live-weight gain/day (lb) & 0.419 & - \\
\hline Birth weight (lb) & $82 \cdot 49$ & $-0.0196 \pm 0.0043^{* *}$ \\
\hline Total milk consumption (pints) & 150.91 & $0.0142 \pm 0.006 I^{*}$ \\
\hline
\end{tabular}

There was no difference between the two treatments in the incidence of scouring.

\section{DISCUSSION}

From the results of Expt $\mathrm{I}$, it is apparent that the addition of lecithin to an homogenized diet was of little beneficial effect, a finding in agreement with that of Bell (1958). The slightly higher adjusted live-weight gain of calves given the diet containing crude, but not the pharmaceutical grade of, lecithin was unexpected and may have been due to some effect other than emulsification. Hopkins et al. (1959) considered such a possibility when they found that crude lecithin markedly improved the digestibility of tallow and coconut fat. Moreover, Allen, Jacobson, Ward \& Zaletel (1956) found that in calves given crude soya-bean oil, the proportion of linoleic acid in the plasma total fatty acids was much higher than in those given a diet containing milk fat, hydrogenated soya-bean oil or lard. However, Spalton (1953) has pointed out that highly purified lecithin is not as good an emulsifier as the less refined grades.

The results of Expt 2 show that under our conditions mechanical homogenization is a more effective method of incorporating fat into a reconstituted skim-milk diet than emulsification of the fat with soya-bean lecithin. The use of lecithin, however, had a slight but not significant beneficial effect on growth rate.

In spite of the often accepted opinion that unemulsified fat causes scouring, particularly in very young calves, the only evidence of digestive disorders in this experiment was a slightly lowered dry-matter content of the faeces in the calves given unemulsified fat. Lecithin significantly increased the dry-matter content of the faeces and also largely prevented the loss of hair from the body that has been associated with unemulsified-fat diets. From our observations, the loss of hair was caused by direct contact with the unemulsified-fat diet and also with the faeces passed by calves receiving this diet rather than being the result of a systemic effect.

Contrary to the results of Expt 1 , in which only the crude lecithin caused a depression in vitamin A level from the 12 th to the 2 rst day, in Expt 2 the purified lecithin significantly depressed the increase in vitamin A between birth and 4 days of age. However, the concentration of lecithin in the diets in Expt 2 was twice that in Expt I. The only other effect of treatment on plasma vitamin A level was a tendency for it to be lower between the I2th and 2 Ist days in the calves given the diet containing unemulsified fat.

The level of plasma lipids during the first 12 days of life was increased in calves given an homogenized diet, whereas inclusion of lecithin had no effect. After the 
I2th day of age, it would appear that homogenization was of less importance, since the blood lipid content of the calves given fat emulsified with lecithin was very similar at 2I days of age to that of the calves given an homogenized diet.

The results for live-weight gain in Expt 3 merely confirmed those obtained in Expt 2, namely that a diet containing homogenized fat gave a better live-weight gain than one in which the fat was emulsified with lecithin. Moreover, intimately mixing the melted fat and lecithin with the dry skim-milk powder, as practised in the manufacture of some proprietary milk substitutes, gave results very similar to those obtained by mixing the melted fat and lecithin into reconstituted skim-milk powder.

It is thus clear that under our conditions we have been unable to confirm the finding of the Cornell workers (Hopkins et al. r959) that mechanical homogenization gives no additional beneficial effect over emulsification of a fat with lecithin. However, their results were obtained with a diet containing coconut fat which had been emulsified with a crude lecithin, and with calves older than those used by us. It must be borne in mind also that a particular emulsifying agent may be more satisfactory with one type of fat than with another.

To be of maximum value, milk-substitute diets should be suitable for calves from 4 days of age. Some reduction in digestibility and utilization of fat during early life may have to be accepted for economic reasons, provided such diets do not predispose calves to scouring and a high death rate. However, in our experience, diets that are slightly inferior nutritionally to whole milk usually cause a very high incidence of mortality once other predisposing factors, such as a build-up of 'infection' (Roy, Palmer, Shillam, Ingram \& Wood, I955), begin to take effect. Thus, when a milk substitute contains a relatively large amount of fat, it would seem advisable to use an homogenized product during at least the first 2 weeks of life rather than one in which the fat had been emulsified with lecithin.

\section{SUMMAR Y}

I. Ninety newborn bull calves were used in three experiments to study the effect of inclusion of soya-bean lecithin in a milk-substitute diet, based on margarine and spraydried skim-milk powder, during the first 3 weeks of life.

2. In the first experiment, the effect of addition to a homogenized diet of a pharmaceutical grade of lecithin and of lecithin in a soya-bean oil carrier was studied. The latter product gave a greater live-weight gain, after adjustment for differences between treatment groups in mean milk consumption and incidence of scouring, and a greater incidence of a high rectal temperature $\left(>102.8^{\circ} \mathrm{F}\right.$ ) and lowered plasma vitamin A and blood lipid levels between the rath and 2ist days of life.

3. In the second experiment, mechanical homogenization of the fat, emulsification of the fat with soya-bean lecithin and addition of the fat without any emulsification were compared. Homogenization significantly increased growth rate and the drymatter content of the faeces. Emulsification with lecithin had a slight, but not significant, beneficial effect on live-weight gain and significantly increased the dry-matter content of the faeces. 
The changes in plasma content of vitamin A between birth and 4 days of age and in the plasma lipid content up to 12 days of age were increased by homogenization. By $2 \mathrm{I}$ days of age, lipid levels of calves given a fat emulsified with lecithin were as high as those of calves given the homogenized diet.

4. In the third experiment, incorporation of margarine and lecithin into the dried skim-milk powder gave a significantly smaller live-weight gain, after adjustment for differences between treatment groups in mean birth weight and milk consumption, than a diet in which the fat had been incorporated by homogenization.

5. For liquid diets based on dried skim milk and containing $2 \%$ of fat, it is suggested that mechanical homogenization should be used in preference to emulsification with lecithin, especially during the first 2 weeks of life.

We are indebted to Mr P. L. Ingram, M.R.C.V.S., Department of Pathology, Royal Veterinary College, for making the post-mortem examination and to Mrs P. Plack and Mrs C. Clough for their assistance in determining the lipid and vitamin A. We are also very grateful to Dr J. Eichberg of the American Lecithin Company Inc. for the gift of soya-bean lecithin.

\section{REFERENCES}

Adams, R. S., Gullickson, T. W., Gander, J. E. \& Sautter, J. H. (1959). F. Dairy Sci. 42, 1552. Adlersberg, D. \& Sobotka, H. (1943). F. Nutr. 25, 255.

Allen, R. S., Jacobson, N. L., Ward, R. M. \& Zaletel, J. H. (1956). F. Dairy Sci. 39, I161.

Aschaffenburg, R., Bartlett, S., Kon, S. K., Roy, J. H. B., Sears, H. J., Thompson, S. Y., Ingram, P. L., Lovell, R. \& Wood, P. C. (I953). Brit. F. Nutr. 7, 275.

Aschaffenburg, R., Bartlett, S., Kon, S. K., Terry, P., Thompson, S. Y., Walker, D. M., Briggs, C., Cotchin, E. \& Lovell, R. (1949). Brit. F. Nutr. 3, r87.

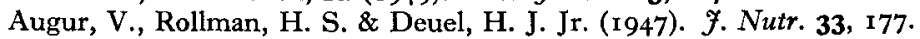

Barker, H. B., Wise, G. H. \& Jacobson, N. L. (1952). F. Dairy Sci. 35, 507.

Bate, W., Espe, D. \& Cannon, C. Y. (1946). F. Dairy Sci. 29, 4 r.

Bell, J. M. (1958). Canad. F. Anim. Sci. 38, 103.

Blaxter, K. L. \& Wood, W. A. (1951). Brit. F. Nutr. 5, 1.

Brüggemann, J. \& Barth, K. (1959). Z. Tierphysiol. Tierernähr. 14, 284.

Clements, F. W. (1949). Infant Nutrition: its Physiological Basis. Bristol: John Wright and Sons Ltd.

Comberg, G. \& Göllnitz, L. (1959). Tierzucht, 13, I50.

Comline, R. S., Roberts, H. E. \& Titchen, D. A. (195r). Nature, Lond., r67, 56 r.

Cunningham, H. M. \& Loosli, J. K. (1954). F. Dairy Sci. 37, 453.

dalla Torre, G. (1953). Latte, 27, 385 .

de Man, T. J. (195I). Tijdschr. Diergeneesk. 76, I75.

Ganguly, J., Kon, S. K. \& Thompson, S. Y. (1947). Brit. F. Nutr. r, iii.

Gullickson, T. W., Fountaine, F. C. \& Fitch, J. B. (1942). F. Dairy Sci. 25, 117.

Haubold, H., Heuer, E. \& Rohusinskyi, R. (1960). Milchwissenschaft, r5, 53.

Hodgson, A. S. \& Murdock, F. R. (1960). F. Dairy Sci. 43, 891.

Homb, T. (1 960). Norg. Landbrukshøisk. Beretn. ForForsøk. no. 99.

Hopkins, D. T., Warner, R. G. \& Loosli, J. K. (1959). F. Dairy Sci. 42, x81 5.

Hopper, J. H., Gardner, K. E. \& Johnson, B. C. (1954). F. Dairy Sci. 37, 43 I.

Huff, J. S., Waugh, R. K. \& Wise, G. H. (195 I). F. Dairy Sci. 34, 1056.

Jacobson, N. L., Brown, L. R. \& Ratcliff, L. (1959). Proc. Distillers Feed Conference, 14, 10.

Jacobson, N. L. \& Cannon, C. Y. (1947). F. Dairy Sci. 30, 587.

Jacobson, N. L., Cannon, C. Y. \& Thomas, B. H. (1949). F. Dairy Sci. 32, 429.

Jacobson, N. L., Zaletel, J. H. \& Allen, R. S. (1953). F. Dairy Sci. 36, 832.

Johnson, B. C., Hopper, J. H. \& Gardner, K. E. (1953). F. Dairy Sci. 36, 599.

Kastelic, J., Bentley, O. G. \& Phillips, P. H. (1950). F. Dairy Sci. 33, 725.

Kesler, E. M., Wilson, J. M. \& Moore, H. L. (1960). Progr. Rep. Pa agric. Exp. Sta. no. 216.

Kliesch, J. \& Horst, P. (1959). Züchtungskunde, 3I, 68.

Larsen, J. B. (1958). Beretn. Forsøgslab. Kbh. $3^{\circ} 3$. 
Lassiter, C. A., Duncan, C. W. \& Christie, L. D. (1957). Quart. Bull. Mich. agric. Exp. Sta. 40, 282. Ling, E. R., Kon, S. K. \& Porter, J. W. G. (1961). In Milk: the Mammary Gland and its Secretion, Vol. 2, Chapter 17. [S. K. Kon and A. T. Cowie, editors.] New York and London: Academic Press Inc.

Lofgreen, G. P. (1950). F. Dairy Sci. 33, 379.

Murley, W. R., Jacobson, N. L., Wise, G. H. \& Allen, R. S. (1949). Y. Dairy Sci. 32, 6o9.

Petrilli, F. L. \& Agnese, G. (1960). Mondo d. Latte, 14, $27 x$.

Raven, A. M. \& Robinson, K. L. (1958). Brit. F. Nutr. 12, 469.

Raven, A. M. \& Robinson, K. L. (1959). Brit. 7. Nutr. 13, 178.

Raven, A. M. \& Robinson, K. L. (1960), Brit. F. Nutr. 14, 135.

Ritchey, S. J., Hopper, J., Gardner, K. E. \& Johnson, B. C. (1956). F. Dairy Sci. 39, 1070.

Roy, J. H. B., Palmer, J., Shillam, K. W. G., Ingram, P. L. \& Wood, P. C. (1955). Brit. F. Nutr. 9, ir.

Roy, J. H. B., Shillam, K. W. G., Hawkins, G. M. \& Lang, J. M. (1958). Brit. F. Nutr. 12, 123.

Shillam, K. W. G. (1960). Studies of the nutrition of the young calf with special reference to the incidence of Escherichia coli infections. Ph.D. Thesis, University of Reading.

Shillam, K. W. G., Dawson, D. A. \& Roy, J. H. B. (1960). Brit. F. Nutr. 14, 403.

Spalton, L. M. (1953). Pharmaceutical Emulsions and Emulsifying Agents. London: The Chemist and Druggist.

Thomas, J. W. \& Okamoto, M. (1956). 7. Dairy Sci. 39, 928.

Tidwell, H. C. (1950). F. biol. Chem. 182, 405 .

Wiese, A. C., Johnson, B. C., Mitchell, H. H. \& Nevens, W. B. (1947). F. Dairy Sci. 30, 87.

Yates, F. (1933). Emp. F. exp. Agric. 1, 129. 